\title{
Differences in the Perception of Health among the Urban Poor Living in Two Squatter House Neighbourhoods in Ankara
}

\author{
Ankara'da İki Gecekondu Mahallesinde Yaşayan Kent Yoksullarının Sağlık \\ Algılarındaki Farklılıklar
}

\section{Yelda ÖZEN* Helga RITTERSBERGER-TILIÇ**}

\begin{abstract}
This study aims to understand the differences in conceptualizations of health and illness among the urban poor. Although the interconnections between poverty and health have been revealed many times, sometimes lumping the poor together into one homogeneous mass. But how poor individuals perceive health and illness has not received much attention sociologically, especially in the Turkish context. This study examined the urban poor's perceptions relating to health through in-depth interviews with 40 participants in two squatter housing neighbourhoods in Altındağ, a district in Ankara. In the study, a qualitative research method was used on the basis of primary and qualitative data. To understand the respondents' health-related perspective, their subjective health and wellbeing; their views about the causation of their illness; how they define/explain health, being healthy, the prerequisites of health and being healthy, and the causes of disease were analysed according to gender, age, poverty experiences and the state of being healthy/ill. The findings show that poverty experiences, age, gender and being permanently sick are influential on perceptions of health and illness. Four constructs were found in the sample: health as the absence of illness, health as tool or capital, health as product or consequence and health as peace and wellbeing.
\end{abstract}

Keywords: Health Perception, Health Construct, Lay perspective, Urban Poverty, Squatter House

$\ddot{O}_{z}:$ Bu çalışma kent yoksullarının sağlık ve hastalık kavramlaştırmalarındaki farklılıkları anlamayı amaçlamaktadır. Yoksulluk ve sağlık arasındaki karşılıklı ilişki çok kez ortaya konulsa da, bazen yoksullar homojen bir kitle olarak görülmektedir. Özellikle Türkiye bağlamında, yoksul bireylerin sağlık ve hastalığı nasıl algıladıkları, sosyolojik olarak çok ilgi çekmemiştir. Bu çalışma Ankara'nın ilçesi Altındağ'da iki gecekondu mahallesinde 40 katılımcıyla yapılan derinlemesine mülakatlarla kent yoksullarının sağlikla ilgili algılarını incelemiştir. Çalışmada birincil ve nitel verilere dayalı nitel araştırma yöntemi kullanılmıştır. Katılımcıların sağlıkla ilgili bakış açılarını anlamak üzere, öznel sağlık ve iyilik halleri; kendi hastalıklarının nedenlerine dair ifadeleri; ve sağlık, sağlıklı olmak, hastalık ve bunların nedenlerini nasıl açıkladıkları/tanımladıkları toplumsal cinsiyet, yaş, yoksulluk deneyimleri ve sağlık/hastalık durumlarına göre analiz edilmiştir. Bulgular, yoksulluk deneyimleri, yaş, toplumsal cinsiyet ve daimi hasta rolü içinde olmanın sağlık ve hastalık algılarında etkili olduğunu göstermiştir. Örneklemde dört sağlık açıklaması ortaya konmuştur: hastalık yokluğu olarak sağlık, araç ya da sermaye olarak sağlık, ürün ya da sonuç olarak sağlık ve huzur ve iyilik hali olarak sağlık.

Anahtar Kelimeler: Sağlık Algııs, Sağlık İnşası, Meslek Dışı Yaklaşım, Kent Yoksulluğu, Gecekondu

\footnotetext{
* Dr. Öğr. Üyesi, Ankara Yıldırım Beyazıt Üniversitesi, İnsan ve Toplum Bilimleri Fakültesi, Sosyoloji Bölümü, Ankara.yozen@ybu.edu.tr

** Prof. Dr., Ortadoğu Teknik Üniversitesi, Fen Edebiyat Fakültesi, Sosyoloji Bölümü, Ankara. helgat@metu.edu.tr
} 
This study explores how health and illness are conceptualized among the urban poor in Turkey. That poverty and ill health are connected has been frequently expressed in academic and public discussion. Research confirms that living in disadvantaged socio-economic conditions means more frequent illnesses, higher infant mortality, greater disability, lower life expectancy, and less access to health services (Benzeval, Judge \& Whitehead 1995; Dodd, Hinshelwood \& Harvey 2004). Health and illness, the object of many sociological studies, have mostly been approached from the perspectives social policy and inequality, leaving the actual health experiences of the poor quite un-researched. Reports by national and international organizations acknowledge the link of poverty with ill health, trying to reduce poverty and promote health indicators through policy. For instance, the OECD and WHO (2003) attempt to improve the health of the poor and prevent the spiral from ill health to poverty through a pro-poor health approach. More recently, key highlights about the linkage of poverty and health were reported by Health Poverty Action (2017). Although quantitative indicators are crucial for policymaking, reducing the poor solely to numbers, they lump the poor into a mass treating them as a passive object of ill-health indicators, rather than as agents or subjects with social relationships, experiences, perspectives, or coping strategies. The existing literature lacks work on how the poor perceive and define health, the factors and experiences influencing their perception, and the patterns underlying their health perceptions. However, there are notable studies of the lay perspective, investigating how health and illness are defined, especially by considering occupational class, ethnicity, age and gender. These studies have uncovered various health constructs (e.g. Herzlich 1973; Pill \& Stott 1982; Blaxter 1983, 1990; Williams 1983; d'Houtaud \& Field 1984; Cornwell 1984; Pierret 1995).

In the Turkish context, however, health and illness accounts have not yet been researched from a sociological standpoint. Since the 2000's, the substantial amount of research into poverty in Turkey to date has only explored poor people's disadvantages -incidentally including healthusing quantitative expressions, but disregarding the poor's personal perspectives. This study aims to remedy this and focus on the lay perspective and relay actual experiences of urban poor concerning health and illness differentiated by social and demographic characteristics.

On these sociological grounds, this study seeks to understand the differences in the perception of health and illness among the urban poor within their social context. Therefore, the main questions are; which factors and processes are influential on their perceptions, how they vary and lastly which patterns of health accounts are specific to the urban poor. The study involved the analysis of the health-related views of the urban poor via in-depth interviews with 40 participants in two squatter housing neighbourhoods in Altındağ, Ankara, namely Baraj and Gültepe. The structure of the conceptualizations of health in the interviews was as follows: selfexpressed subjective health and wellbeing, perceived causation of wellbeing/illness (es), definition of health and being healthy, and views on the causes underlying health/being healthy and/or ill/ness. The perceptions were analysed by factors: gender, age, poverty experiences and the state of being healthy/ill, to understand the different perspectives on health among the urban poor.

\section{Lay Perspective on Health and Illness}

Medical sociologists have investigated the sick role, illness behaviour, health beliefs and the perceived causes of illness for over 50 years. After so much focus on all these aspects of illness, they have only recently shifted their attention to the sociology of health and the lay perspective (Lawton 2003). Lawton $(2003,25)$ emphasizes that the "outsider perspective" has replaced the "insider perspective" within medical sociology. This increasing interest in the lay perspective 
and thus the interest in perceptions and everyday life experiences on health and illness can be attributed to a number of developments: the growing criticism of the biomedical paradigm including medicalization disputes and questioning "expertise"; the growing importance attached to studying chronic illness experiences due to changing morbidity and mortality patterns, and the ageing population; and the rise of the discourse of healthy lifestyle and healthiness. "There has been a gradual shift away from explaining health-related behaviour simply in terms of "health beliefs", towards attempting to understand the lay person's actions in terms of their own logic, knowledge, and beliefs, which are grounded in the contexts of people's daily lives" (Williams 1995, 580). As such, the study of illness experiences as narratives, chronic illness and lay belief and knowledge has garnered greater attention (Bury 1982; 1991; 2001; 2005; Williams 1984; Pierret 1995; 2003; Nettleton 1995; Lawton 2003). How health is conceptualized by differing social categories has also received interest. These studies indicate that health has various aspects and is influenced by a variety of social factors. There are various studies on the lay perspective, the well-known studies done by Herzlich (1973), Pill \& Stott (1982), Blaxter (1983; 1990), Williams (1983), d'Houtaud \& Field (1984), Cornwell (1984), and Pierret (1995) are reviewed within the scope of the research.

The pioneering study of Herzlich (1973) examined lay ideas about the causation of illness and ideas of health by interviewing 80 respondents from the middle and intellectual classes from Paris and Normandy. It was found that the "respondents distinguished clearly between illness the negative concept- which was produced by ways of life and especially urban life and the positive concept of health, which came from within" (Herzlich 1973, cited in Blaxter 1990, 14). According to the study, health is internal to the individual and illness is regarded as something coming from the external world. Herzlich's study also established three main social representations of health: "health in a vacuum" (absence of illness), "reserve of health" (associated with person's constitution and resistance), and "health as equilibrium" (positive state of wellbeing).

Another important study was by Pill and Stott (1982) about the subjective aetiology of illness, analysing interviews with 41 working class mothers aged between 30 and 35, living with a husband and two or three children aged 5-11. The findings state, "at least half of the sample of working class mothers held fatalistic views about illness causation and were prepared to accept the concept of blame only under very restricted circumstances involving direct risk taking" (Pill $\&$ Stott 1982, 50). Women most frequently state external causes (germs, viruses, infections). This indicates that the medical model of disease based on germ theory has penetrated lay people; thus, medical and lay perspectives may not be opposing views, as Helman (1981) and Blaxter (1983, 1990) point out.

Blaxter's 1983 study was based on data gathered for research conducted by Blaxter and Paterson in 1982 in Aberdeen. She examined the concept of disease and its causes, revealing the difference between the medical view and lay perspective about the causation of illness through interviews with 46 middle-aged women in semi-skilled and unskilled manual labour classes, brought up in disadvantaged circumstances. Her findings are similar to Pill and Stott's: "infection is the most important category of cause" (Blaxter 1983, 61), followed by hereditary and familial tendencies, agents in the environment such as poisons, working conditions, climate, with the least stated causes being behaviour-related, self-responsibility, ageing and natural degeneration. Many studies show working class people and poor people tend to see illness as coming from the external world, denying any responsibility for health. Experiencing poverty during childhood seemed to influence women's definition of health and the perceived causes of 
disease. Blaxter $(1983,68)$ concludes that "cause is multifactorial, processes are interconnected, manifestations are multi-faceted and mind and body are not differentiated", and the folk concept of disease does not differ greatly from the medical explanation; women link their explanation with their life experiences.

A crucial study for the age dimension, Williams (1983) studied the concepts of health among elderly Aberdonians using two data sources; an intensive study of two social networks and a random sample survey. He found three lay concepts: "health as the absence of disease"; "health as a dimension of strength, weakness and exhaustion"; and "health as functional fitness".

D'Houtaud and Field (1984) examine health perceptions for different social classes using a sample of 4,000 respondents from different social classes, from Lorainne in France. The study found non-manual classes tend to explain health "more in personalized, positive and expressive terms", and the lower manual classes conceive health "more in negative, socialized and instrumental terms" (d'Houtaud \& Field 1984, 30). Like Lawton (2003, 31), the study showed "predominantly manual lower classes tended to evaluate health in terms of its physical attributes, as a means to an end, in which the body was seen as the instrument for achieving that end". A study on the meaning of the body done by Shilling (1993) similarly found that working class people's orientation towards illness and the body is conceptualised as "a means to an end" while middle class people treat the body as "an end in itself".

Cornwell (1984) explored the gender dimension using accounts of health and illness from East London through 24 interviews ( 15 women, 9 men), and found the gendered division of labour, everyday life hardships -therefore the social context- as crucial to women's definition of health, illness and responses to illness.

Blaxter's other study (1990) highlights the variety of definitions people use to describe whether they and others are healthy. The survey involved 9,000 respondents across the UK in 1984-1985, finding that older people who feel their stock is diminishing explained health negatively unlike young people. Health as functioning becomes important for old age, too. Regarding gender, she states men under 40 define health as fitness, and younger women as good social relationships with family and children: "being able to cope with family problems" and "having more patience with them" were frequently included in definitions of health for themselves (Blaxter, 1990, 27). For older women, "serving other people, being in a position to help others, having sufficient energy to care for others" was frequently mentioned as the marks of good health (Blaxter, 1990, 27). Respondents' definitions are categorized as: "health as not being ill", "health as a reserve", "health as being fit for function", "health as physical fitness", "health as a behaviour", "health as a good social relationship", "health as a positive vitality", "health as a feeling of psychosocial wellbeing", and "health despite disease".

Similarly, Pierret (1995) holds that an individual's type of concern about health matters and their general ideas about health change according to occupational class. According to her, there are four constructs of health: "health as illness" (not being sick), "health as a tool" (when you have health you have everything), "health as a product" (as an objective to be reached), and "health as an institution" (matter of public policy and institution). She found, "for those with manual occupations whose bodies were "tools" or "implements" used on the job, health was seen in relation to work, as both the ability to cope and the absence of illness" $(1995,21)$. For middle class people, however, health was the center of attention. While ideas about the health of manual workers and small-farmers corresponds to the "health-illness" and "health-tool" constructs, mid-level private sector employees usually prioritize pleasure and their view of 
health corresponds to the health product construct. Lastly, public sector wage earners' understanding of health corresponds to the health institution construct.

In the Turkish context, the sociology of health has room to grow. To our knowledge, no study has directly integrated gender, age or social class into an analysis of health and illness conceptualizations in Turkey. There are some contributions that can be considered as approaching in an indirect manner.

Many studies touch upon the issue of health as a basic service people should access, and focus on health problems frequently affecting the poor; poor people's practices coping with health problems; and the relationship between their employment, health insurance status and health problems (e.g. Boratav 1995; Lordoğlu \& Özar 1998, Kardam \& Yüksel-Alyanak 2002; Ayata \& Ayata 2003).

Ayata and Ayata (2003) investigate the various aspects and specific processes concerning poverty in Turkey using qualitative data from fifteen provinces. They distinguish two groups of poor: the first, defined as benefit dependent poor (extremely poor), involves the unemployed and casually employed poor depending on benefits from formal institutions or informal networks; these include the sick, disabled, unemployed, female-headed households and unskilled uneducated casual labourers; the second group, the regular income earning poor, comprises families with relatively higher incomes and features at least one family member regularly employed albeit on minimum wage or an amount only slightly higher. The two groups are different in terms of healthcare access, health seeking behaviour, frequently seen diseases, and problems faced in medical institutions (Ayata \& Ayata 2003, 125-128). In terms of health, Ayata and Ayata state ill health limits job prospects, making it a major source of low income and poverty. The results show ill health prevents regular work, forcing employment such as garbage picking, street selling, and shoe shining on a part time, casual or temporary basis. Ayata and Ayata stress how poverty creates a vicious circle where low-income, social insecurity, vulnerability and ill health mutually reinforce each other by assuming health as an important dimension of poverty.

Some crucial studies exist on the sociology of health and illness in Turkey. Among them, Türkdoğan's (1991) study on health and illness systems in rural areas; Akşit and Akşit's study (1989) on socio-cultural determinants of infant and child mortality and also on the role of mother's education on infant mortality (Akşit \& Akşit 1997); another research made by B. T. Akşit (1993) on rural health seeking under age five; Kasapoğlu's study (1999); and Adak's study (2002) are the first crucial contributions. Studies carried on by Gürsoy (1992, 1995, 1996), Kasapoğlu (2008), Cirhinlioğlu (2000), Özbay, Terzioğlu and Yasin (2011), Alptekin (2015), and Adak (2016) are also prominent.

Notable among these, Adak's study included her analysis of women's conception of health and illness and causation of illness. She (2002) examined the attitudes and behaviours of women aged 15-49 living in rural and urban areas in Antalya. According to the findings, $18.4 \%$ of the participants perceive health as physical health, 9.4\% mental or psychological health, $17.3 \%$ health as an absence of illness, $5.5 \%$ health as wellbeing, and $1.6 \%$ as the capacity to perform daily tasks. About half emphasize all of the above in the definition. In the study, diseases are expressed as being influenced by malnutrition, stress, microbes, cold and bad habits like alcohol use and smoking, respectively.

There are also dissertations on the sociology of health and illness (e.g. Tekin 2007; GelgeçBakacak 2008; Gönç-Şavran 2010; Öngören 2011). Among them, Gelgeç-Bakacak's thesis (2008) stresses the lay perspective on health/illness, mental health/illness and mentally ill 
people via 45 interviewees categorized by sex, age, and educational status. The study shows the health and illness definitions of individuals on coping with illness and consequences of illness are in four categories: "weakness in physical activities", "evident symptoms", "psychological situations", and "problems experienced in social life".

An analysis of the Turkish academic literature shows, that the health perceptions of urban poor have not been considered in opposite to the international literature. So, with this paper the authors aim to explore this neglected area of health perceptions of urban poor in Turkey.

\section{The Fieldwork: The Urban Poor in Two Neighbourhoods in Ankara}

The aim of the study was to understand how the urban poor within their social context conceptualize health and illness. In accord with the objective of this study, in-depth interviews were held. The research was conducted in two neighbourhoods, namely Baraj and Gültepe in the district of Altındağ in Ankara, through face-to-face in-depth interviews with 40 individuals in the autumn of 2005. The interviewees were selected in three stages. First, a district, Altındağ, was selected by examining central district-based socio-economic and health statistics obtained from the State Institute of Statistics and the Health Directorate of the Province of Ankara; then the neighbourhoods, Baraj and Gültepe, were chosen after upon suggestions from official experts (Social Aid and Solidarity Foundation and the Health Group Directorate), and lastly, the participants were selected using the snow-ball technique. Two key informants living in each area for a long time and the neighbourhood chiefs provided guidance. They identified lowincome households with members having casual jobs, unemployed, chronic patients, uninsured or those receiving social and health assistance. Afterwards, the interviews proceeded as snowball.

In each selected household, one member, eighteen or older, was interviewed. All interviews were recorded and transcribed. The participants decided the date and time of the interview. Before beginning, they were informed about the content of the research, the time, the confidentiality of the data gathered and their right to withdraw. The names and some features identifying them were changed to assure anonymity.

There were 20 male and 20 female participants (Ages 20-78), many of working age. The educational status was homogenous with most having been to primary school. All the participants or their parents had migrated from rural areas. The majority were born in villages. The rest were second-generation migrants born either in Ankara or other cities in Turkey. The majority of the participants had migrated to Ankara between 1975 and 1999, with few newcomers having migrated in the last 5 years before the research. Regarding the relationship to the head of the household; 15 were the head of the family and 15 were spouses. Other than household heads and spouses, a son, mother, father, and the brother of the head of a household were interviewed.

As for employment status; there were unemployed participants, housewives, retirees, and workers employed in informal or formal sectors. While almost all of the working participants were employed in the informal sector including self-employed and employees such as casual workers with no social security, and there was only one formal sector employee with social security.

\section{Economic and Work Conditions, and the Health Status of the Urban Poor}

In terms of work life, the urban poor find employment in the informal sector. The informal labour market, with its low/irregular income and unsafe, insecure working conditions, is 
exploitative in character. Though it provides a way for the poor to subsist in the urban area it also sustains their poor status.

Although urban poor have similar experiences, they are not a homogenous mass in terms of socio-economic status and healthcare access. This study utilizes Ayata and Ayata's (2003) conceptualization of families: benefit dependent poor (families whose members are unemployed or casually employed without being insured) and regular income earning poor (families who have higher income than benefit dependent poor where at least one member of the family is regularly employed and insured). The benefit dependent poor include both irregular income earning poor such as casual workers, and no income earning poor who do not earn an income from wage work due to illness or disability. There are 24 benefit dependent poor families and 16 regular income earning poor families in the studied group. Among the benefit dependent poor, there are 5 families with the single breadwinner no longer able to earn money from wage work due to an existing chronic disease, for which treatment is received. The benefit dependent urban poor's employment status and their jobs limit their and their family members' access to health care, because health care access is dependent on having a registered job in the formal sector.

In terms of perception of impoverishment, almost half of the respondents stated their socioeconomic condition declined after migration and more than half of the participants expressed that they have been living in worse economic conditions for about 10 years. Their work histories show that the family members of nearly all hold a benefit dependent poor position, working in the informal sector with irregularly earned wages. In addition to their weak attachment to the labour market and the characteristics of employment, the onset of chronic disease can also cause impoverishment. Participants who think that they live in slightly better economic conditions are few and almost all are among income earning poor families. The perception among the participants that their economic situation has improved is closely associated with having a full-time, regular job with insurance, and being able to retire. Also, very few participants whose motive for migration was better living standards in the city and getting rid of rural poverty report that there is no change in their economic conditions since they settled in the city.

In terms of illness, the urban poor seem more vulnerable to both infectious and chronic illnesses. Their illness experiences can be attributed to work-related factors, employment status, malnutrition and economic hardship. It is found that living in poverty and having unmet basic needs first affect children. For adults, illness may result in the loss of a job, or changing jobs, but it almost always means working for less money. Typical examples are a herniated disk due to hard physical labour; or pneumonia due to unhealthy living conditions; or depression, which is actually among the most frequently cited illnesses.

Chronic illnesses are commonly seen among adults and the elderly and among some younger people. While children frequently catch infectious diseases such as influenza, strep throat, pneumonia, bronchitis, excluding congenital diseases, the elderly and adults have chronic illnesses such as asthma, hypertension, heart disease, diabetes mellitus, rheumatoid arthritis, cancer, kidney failure, glaucoma, coronary artery disease, ulcerative colitis, stroke, osteoporosis, hepatitis, and chronic bronchitis. The majority of those having heart disease and complaints of heart palpitations and pain are male. While many are household heads, some transferred this responsibility to their sons due to illness. They believe their economic circumstances have recently worsened and are actually benefit dependent poor. While hypertension is common among the elderly, many adults and young individuals also suffer. Among children, there are cases of hip dislocation and amblyopia, growth deficiencies and 
hormonal imbalance. Various childhood diseases are frequently seen among benefit dependent poor families. They suffer both from unmet basic needs and the lack of access to health services. They mention that the breadwinners' change of employment status or sector causes changes in insurance status, resulting in interruptions and delays in treatment.

Another common illness among the urban poor is herniated discs. All women who have worked as house cleaners suffer from this illness. Also, the male members of the families whose work involved carrying and lifting heavy loads are similarly afflicted. In addition to occupation, benefit dependency is a factor. Their illness experiences influence their lives negatively; causing some to leave employment, some to take part-time jobs and others to suspend employment.

The other most common illness is depression. More than a quarter of the families have sick members suffering from medically diagnosed depression. Although some have been treated, the majority are still suffering because their experiences with survival and economic difficulties are either the same or have worsened, as reported by the informants. Also many individuals report feeling dejected, stressed or depressed but without having actually seen a doctor. These kinds of health problems are much more common among women who are among the benefit dependent poor and strongly feel recent impoverished.

\section{Subjective Accounts of Health and Wellbeing}

\section{Physical/mental health and wellbeing}

The participants provide three typical descriptions for their self-perceived overall health and wellbeing: bad, in-between, and good. However, what they mean by healthy varies. They distinguish between physical and mental health and overall wellbeing. Although many focus on one, the participants usually link mental and physical health. However, when the conversation progressed, they assert that these two are intertwined.

Participants who state having good wellbeing are not a homogenous group, but one of three subgroups: those who express good wellbeing and mental and physical health; those who express good wellbeing and "Thank God for this" although they have illness complaints and/or mostly mental problems; and those who report feeling good despite suffering from a chronic illness for a long time. In the first subgroup, the number of participants responding "good" both mentally and physically is very small ( 2 participants). What they share is that they are male household heads, have no medically diagnosed illnesses and have full-time jobs. In the second subgroup, there are a few participants who feel bad mentally and/or physically but state their overall health and wellbeing as good. Their statements involve expressions of "Thank God" because they are not disabled, worse, or physically dependent on others. In the third subgroup, in which participants describe their wellbeing as good, they feel good mentally but bad physically and are both regular income earning poor and chronic patients. They tend to focus on their illness and its severity when providing explanations. All of them have been chronically ill for a long time and state having internalised this and living with their illness.

The majority of all participants report being unhealthy and they feel bad mentally and/or physically. In this group, while most participants view their condition as bad physically and mentally, they focus on economic reasons, but others focus directly on the illnesses they are experiencing. While almost all benefit dependent poor tend to focus on economic difficulties when defining their health and wellbeing as bad by focusing especially on mental health, elderly income earning poor with chronic illness (es) tend to define their sense of being unhealthy by focusing on their illness experiences and the severity of their illnesses. Furthermore, all participants who have recently been diagnosed as chronically ill, express feeling unhealthy. 
Furthermore, adult breadwinner participants unable to work due to the onset of a disease, highlight that they feel bad mentally and physically. Among those who reported bad health and a low level of wellbeing, some report feeling bad mentally but good physically. They are much younger participants working in the informal sector and don't have a chronic illness. Also, many, especially housewives suffer from depression, feelings of dejection, and headaches because of irregular income and survival/subsistence problems.

It is striking that few participants feel bad both mentally and physically, but state their overall health and wellbeing as in-between. Among those, the explanations of overall health as in-between or changeable are given according to illness experiences such as pain and severity of illness.

\section{Perceived prerequisites of health and wellbeing and causes of illness}

The urban poor's perception of the prerequisites of their health and wellbeing provide clues about how they conceptualize health and illness. The physical and/or mental health and wellbeing of the urban poor varies according to their poverty and illness experiences, age and gender. When they describe their state of physical and/or mental health and wellbeing as bad, most of them are focusing on living in poor economic conditions with low and irregular income, difficult working conditions, long hours, an employer's tendency to not pay wages and delay payments, health risks and threats, job-hopping, high likelihood of being unemployed, unemployment, non-insurance; in sum, precariousness. Moreover, it is observed that the effect of gender and illness experiences on the conceptualization of health/wellbeing is not independent from experiences of poverty. The analysis of the responses shows that as perceived causes of their illnesses only a few mention genetic or congenital reasons, fatalist or religious causes, behavioural reasons or specific events, all of which are expressed mainly by regular income earning poor, retired, elderly and chronically ill respondents. But the rest of the participants do stress economic reasons. The interviews display different perspectives regarding the perceived causation of health and illness: earning a livelihood from low-irregular income, being unemployed, being elderly and/or chronically ill, and being women emerge as different experiences.

\section{Making a living on a low-irregular income}

Low and irregular income entering the household adversely affects the members' health and wellbeing. The majority of the participants mention being depressed due to low and/or irregular wages. A freelance housepainter M.K. (male, 33) states that whether he feels healthy or unhealthy depends on his economic conditions. Asked about his health, he reported feeling healthy physically, because he can go to work and earn money despite suffering from tachycardia. However, his mood in general is not good, because his income is irregular. M.K. and his wife point out the effects of poverty experiences on their wellbeing:

M.K: There have been many upsetting experiences. You have a hard time, your phone is disconnected, your electricity is cut, and you get stressed.

Wife: Then the kid comes, I want to buy a book, I want to buy this, I want to buy that and it is hard when you cannot. Then you start thinking trying to find a way out.

M.K: We had gone back to the village because of the religious holiday. We came home. We had just. Closed the door and the doorbell rang. They said either you have to pay your electricity bill within 5 days or it 
will be cut. The water bill arrives. I checked the phone, its disconnected. Of course, it naturally causes stress even if you have 100 Turkish Lira in your pocket. You do the math; if I pay the bills, what will the children eat? So, be it if they cut it. Even if you have to pay interest later, after 15 days, you pay it next month. But of course, you can't help it; lying in bed you wish you could pay the electricity bill, the water bill, you wish you could buy the kids something, you get stressed. We can't sleep then. We both turn in the bed. Sleep if you can. Half of the month goes by like this, all upset. The more you think about it, the worse you feel.

The participants' employment histories show informal sector manual jobs have unpredictable, flexible working hours, offer low and irregular wages, involve health risks, lack social security benefits and safety. In terms of income, as well, there is no guarantee the employer will pay the wages on time.

Distinguishing their health and poverty experiences is no simple matter. Based on the observations during the course of interview, health and poverty are perceived as directly interrelated. The irregularity of income not only come up while discussing their income; respondents emphasized irregularity, repeatedly, in the context of their future expectations, health, poverty experiences, and suffering. It determined their wellbeing, food consumption, and sense of being healthy. Illness could be a consequence of poverty and employment conditions, and at the same time, it could be a cause of poverty. The emphasis on irregularity and extreme economic hardship is frequent among the benefit dependent poor and among those who feel they have been impoverished for some time. Participants who have chronic illnesses emphasize their illness experience to explain their wellbeing. M.H. (male, 33) states:

I am forgetful. I have headaches, depression and heartache. My wife has been in depression for 9 years. My daughter has delayed development. It's all because of destitution and malnourishment. We are not well. I have had an ache in my heart for 10 days. We work no matter what. I don't think about it too much in the summer while working, so its better. In winter, I am angry and don't know what to do with myself all day. I think about if I will have a job in the summer. You think about how you will get by this year. For 3-4 years we have been mentally and physically unwell. Stress, poverty, and unemployment.

The working conditions of the urban poor are crucial for two reasons: First, working conditions help perpetuate the vicious circle of poverty; and second, this affects the body and health and these people's health experiences.

In the informal sector, porters or construction workers are subjected to health risks such as extreme exhaustion, sleeplessness, and back pain due to long working hours in physically taxing jobs. The precariousness of the job and the state of health and wellbeing of the urban poor are closely related. For example, long working hours cause exhaustion, and working night shifts lead to sleeplessness and irregular sleep, as reported by M.B. (male, 51). He complains about his job:

Casual work is heavy work, it wears out the body. In fact, I am not a young man. The job causes extreme exhaustion and back pain. After the end of the job, my whole body aches. But there is no alternative. Sometimes, I lift heavy things for hours on end. I work in construction 
sites. Of course, it is dangerous.

Many participants also state that poor living conditions and the informal work itself have cumulatively damaged their health since they migrated to the city. S. K. (male, 70), who was able to retire after working under difficult conditions, says:

I have lots of illnesses, because I have always worked in jobs with difficult working conditions. I unloaded and carried loads weighing a total of 700 tons a day all by myself. I carried wheat to an agricultural office, I worked for an iron and steal factory, in an electric plant, in farms, in hazelnut fields, in a coal warehouse, as a casual worker, and truck driver and porter. I went everywhere, to lots of different cities. Those days my wife stayed at home. I would be away until the job was done and come home once a month. I am 70 years old now, but I stopped working in 1997. My life went like this. Now, I have all kinds of diseases. But I endured this kind of hard and long work. I have rheumatism arising from working in different places. I also have a hernia from lifting heavy burdens.

S.K.'s work history involves many jobs under insecure and unsafe working conditions. In spite of how long he worked (1954-1997) both in the formal and informal sector, he was able to retire in 2003, having finally been able to pay off his insurance premiums. Now he suffers from many illnesses as a result. Working for a long time especially under difficult and unsafe working conditions increasingly wears out the body over time, as was also expressed by many participants.

\section{Being unemployed}

Among the participants, unemployment is regarded as important both as a cause and result of illness. The severity of the harsh working conditions leads to health problems, which, in turn, prevent the urban poor from working, whether temporarily, permanently or force them to work less or part-time. The working conditions are very flexible and pose a threat for health and wellbeing. The health and safety of the worker who is the breadwinner of the family affects not just the worker, but the whole family.

In the sample, the concept of poverty is closely associated with unemployment, instability, difficulty getting by, or barely surviving. It is clear that low and irregular income is closely associated with mental health, wellbeing, depression, helplessness, and stress. That poverty reinforces depression is frequently seen among the unemployed, the chronically ill and the unemployed, the unemployed housewives whose husbands are casual workers, those selfemployed in the informal sector and marginal sectors, as well as casual workers and selfemployed in the informal/marginal sectors.

Many participants have family members medically diagnosed with mental health problems after falling into unemployment. M.A. (male, 30) lives in a regular income earning poor family. His father is retired and has a small pension salary. The close association between unemployment and mental health is expressed as:

I am depressed, because I am unemployed. I consider suicide; every living minute. I see it as the only way out. I have attempted suicide before. I always think about it. My dad gets a pension. Maybe it isn't a big problem for others; but it is for me. I can't bear it. I am 30 years old 
and I am ashamed. When I lost my job, my wife left me. We got a divorce 4 years ago. We got married 4 years ago in 2001. We stayed married for 50 days. I am in depression due to unemployment. I constantly think about suicide. I go to interviews everyday but to no avail. I see death as salvation. If I would find a job, I would be rid of depression.

Being chronically ill and unemployed is a specific experience. There is a feeling of helplessness due to the illness and not being able to cope with poverty. N.T. (male, 45) has hepatitis and has to work to provide for his family. In the research, chronically ill participants are either unemployed or work in marginal jobs. This indicates a pattern that living in low and irregular income, as a chronically ill person, influences wellbeing negatively:

It's upsetting of course. It's because of unemployment. You come home, you have a look and there is no food or drink. Your children aren't comfortable. You can't do anything. You are helpless. I think; I am a father, so, of course, I get upset. I go to Dörtyol thinking I can do something like sell simit or pastries. But people ask me what I am thinking. I tell them they can't know what goes on inside me. They tell me, they will take me to a doctor, I ask them how they will be able to do that. It gets to you. I always feel bad both, the illness and destitution.

Other unemployed and chronically ill participants state that ill health limits their job prospects, becoming a major source of poverty. They also state that being ill forces them to work in relatively easy jobs such as garbage picking, street selling, and shoe shining on a part time, casual or temporary basis: therefore, ill health prevents the sick person from doing regular work. The permanently sick who work, also regulate their working days and hours according to the severity of their illnesses at a given time. Being unemployed and sick makes them feel they are failing in the role of main provider for the family. This feeling is closely related to the traditional gender roles in Turkish culture.

In short, experiencing unemployment damages wellbeing and mental health on the one hand and being sick is an important precursor to unemployment on the other. Also, there are cases where individuals experienced loss of work, owing to work related illnesses, and this experience triggered mental problems. Casual workers are assumed to be among the employed and unemployed because they frequently fall into the unemployed position, especially in winter. The precariousness of jobs, i.e., lack of job insecurity and the accompanying constant risk, adversely affects mental health and the wellbeing of family members.

\section{Being elderly and/or chronically ill}

Approximately half of the participants suffer from long-term illnesses. Chronically ill and older participants say that they feel bad, especially by focusing on their physical health. This pattern is quite clear among the retirees, and/or those who have a working family member in their household. Almost all older participants have a chronic illness and many tend to provide fatalistic explanations about their wellbeing. Although they have slightly better economic conditions compared to the past, the emphasis on poverty experienced deeply in the past is still made by many participants. For those chronically ill, wellbeing depends on the severity of the illness. For example, G.B. (female, 49) suffers from high ocular pressure, hypertension, and depression. She states that she feels bad both mentally and physically, and her wellbeing is changeable. She states that the severity of her illness depends on the weather conditions and the severity of her husband's illnesses at any given time. Although she is somewhat better off 
economically than she used to be, the health related consequences of living in poor conditions have not completely disappeared.

Although chronic patients and/or the elderly tend to emphasize either their physical health by focusing on physical pain and inability or wellbeing by focusing on economic hardship in their health definitions, they also attribute mental health and wellbeing to their sick role identity in the family and wider society. Sick participants describe their wellbeing negatively due to the treatment they receive from others, how they are labelled because of their illnesses, excluded from their social environment and families. Feeling of exclusion is more frequently reported by younger participants with chronic illnesses. A.M. (male, 35) suffers from skin cancer. His bodily representation, the colour of his complexion post-treatment leads to stigmatization when he is applying for a job, when he is in a hospital, or on a bus. Not only does he suffer from the consequences of his illness, he also has to deal with society's reactions, such as the negative reactions of his neighbours, when he follows medical advice. He says:

I don't have a chance of getting better. I have a 90 percent possibility of going blind. My vision is cloudy. Colours blend because of my illness and the medication. I need to wear those glasses 24 hours. But then people make fun of me. It's their shame. The neighbours do this. I can't work, because I have skin cancer. Now I can't go out in the sun. I have radiation therapy 3 days a week. I tell them this when I apply for work and they say, they don't need me. Well, I need you, but I can't hire you, they say. My illness started in 2001, 4 years ago. I have had phototherapy and chemotherapy. I am not old. I am 35 but my peers are all working, at least they have holidays and sick days. Look at my colour; who would hire me? The machine does it and I am dark anyway. I really want to work but no one will give me a job so I lose all hope. Another blow from there and I am left with my illness. Wherever I go, I feel like a stranger. In the hospital, on the street, on the bus, looking for a job... Do you know why? My colour. It is very different. I walk into a hospital and everyone stares. People find it strange to be so dark. You feel guilty. They make you feel that way. But why is this so, what did I do? I went to an office to apply for a job. He looked at me and said he couldn't hire me. He said it was because of my colour. I am discriminated against, everywhere.

Like A.M., chronically ill participants' subjective view of their health and wellbeing is shaped not only by their illness experiences, restricting their everyday life, but also being in a permanent sick role with all of its connotations, attributions and imagery in society. In addition, the sick role may force them into a dependent position in the family. The attachment to the urban labour market disintegrates over time, causing either complete disconnection or a weakening of the ties according to the severity of the illness. This causes a change in position as well. Many chronically ill participants who have passed on the breadwinner position are uncomfortable. This influences their wellbeing negatively. Becoming sick, in general, is equated with becoming dependent, which forces the ill individual into a different position in society. The excerpt below is such an example. H.A. (male, 48) transferred his breadwinner position to his 24-year-old son just three months earlier. He says:

I don't know if it's from the work I do but my health is bad. I have stress. I have a heart disease for 8 years and an ulcer for 5 years. I have had 2 
heart attacks. I feel bad when I am upset. I can't take long rides anymore. You are sleep deprived if you go. If you go, they tell you to lie down in the car and it's cold. So I don't go anymore. I wouldn't have gotten this way if it wasn't for my problems at work. I used to go to Siteler to work until last week. I helped if there was furniture to be carried. But now my heart is failing, so I get tired easily. I used to be fine. Now my son has been working for 3 months. If only we could just pay off the credit card. My son got engaged, so we owe 3000 Turkish Liras in credit card debt. My ulcer is because of stress, too. At least the kids are growing up. I can't work much. My stress is never over. I can't do the things I like, because I am sick. Within two years I worsened. I was comfortable before. These last few years have been bad. Unemployment and sickness have destroyed me.

He mentions attempting to work daily as a porter until one week ago, but realized he was incapable due to symptoms worsening, when he was working. On the one hand, he complains about not working due to illness, on the other hand, he sees his sons as the security of the family's future.

These narratives elucidate what these chronically ill people perceive as the prerequisites of wellbeing. Few chronically ill participants focus on genetic and congenital reasons, and very few attribute their illness to God. Traffic accidents and specific familial events, like the death of a family member also rarely come up. Most frequently mentioned causes of their own illnesses are related with poverty experiences, even for those who are regular income earning poor families. They see being healthy or ill, as being related to their present economic condition, as well as the long process and history behind it. Most of the chronically ill participants attribute their illnesses to lack of fulfilment of basic human needs, lack of regular income, lack of adequate food, lack of proper care due to unsanitary conditions, subsistence difficulties, lack of a warm living and working environment, difficult and insecure working conditions, stress, dejection and unemployment.

\section{Being women}

The subjective expression of health and wellbeing also varies by gender. In the study, poverty is experienced differently by the genders, and traditional gender roles are seen as influential for the health and wellbeing of participants and what they perceive as the causes of their illnesses. In their work histories the families reveal that women have a weaker attachment to the labour market and have work experiences mostly in the informal sector, notably for shorter time periods compared to the men. It is seen that women work(ed) before under difficult and exhausting conditions for long hours without social security. They also earned lower wages than men. T.D. (female, 45) worked as a house cleaner for six years. She describes the exploitative character of her job:

I worked as baby-sitter, patient care worker, and maid. But these jobs destroyed me. Now I suffer from a herniated disk because I had to clean other people's filth. The last time when my disease was newly diagnosed, my friend found a job for me. The job was baby-sitting and the mother of the baby was a woman medical doctor. She demanded baby-sitting, housework, and also her mother's housework. I said thanks, but you need to find a good worker to handle all of those. I said that I was not a 
machine. I said its okay, I would clean your house, I take care of your baby, but your mother's housework is not my business. Nobody should be exploited like this. I could not work afterwards anyway when my pain worsened.

T.D started to work after her husband squandered his wages instead of providing for the household. Her only option was a job in the informal sector. Manual jobs with difficult working conditions have exceptionally negative influences on the health status of individuals, says T.D.. Though working in the informal sector seems like a solution for survival, the result is greater poverty since the long-lasting physical effects ultimately cause unemployment.

H.A. (female, 27) mentions the exploitative and time-consuming characteristics of her work. She knits berets at home and she gives them to a shop to be sold. She makes very little money. She says:

Two children and deprivation, you can not buy the things the children want, every time something is missing. I always have to endure these sufferings. Again and again, I have to say "no" to my children. I knit in order to contribute to the household income. The more I knit the more money I earn. I receive 2 Turkish Liras per beret. If I knit 10 berets per day, the wage is 20. I try to knit 5 berets per day working day and night. Sometimes I receive an order and I try to make the deadline and I work through countless nights for this reason. I get very tired. It is hard work. My husband does not let me work out of the home.

Piecework describes types of employment in the informal sector, in which the worker is paid for each unit they produce. In order to earn more money, they work longer hours. This is a strategy women use to cope with poverty. In our sample, the majority of the housewives are willing to work outside their homes. They do not want to sit at home and do nothing in the face of poverty. They strive, despite the cultural patriarchal values dictating strict roles and obligations. Their husbands do not let them work outside the home as in H.A.'s case. Therefore, the contribution they can make is through working at home. In such cases, women's ability to fight against poverty is determined by power relations inside the family and is supported by domesticpatriarchal ideology.

Women participants emphasize that they have unique experiences of poverty, because they can not use their capabilities to participate in economic activities to fight against poverty. They state that this has negative consequences on their health. M.Ay (female, 35) had a formal job before getting married. Her husband does not allow her to work. She reports bad health and wellbeing. She says:

I have no choice but to be a housewife. I have two children. What can I do? Actually, if I didn't have children, I would wrest a living from the soil. I was a working woman, I was doing alright. When my little son begins school, I will go back to working. My husband does not let me work but then I will pay him no mind. If you are poor, being a housewife is difficult. You stay home with the children. They see a banana on TV, you can not buy one. They want everything. You try to manage. It is difficult. I am ashamed of not being able to do anything. It makes me upset.

The excerpt summarizes the experiences of women who want to deal with poverty but cannot 
use their capabilities to earn income due to their domestic responsibilities and the unpermissive attitude of their husbands. It is possible to say that women have a different experience of poverty from men; they experience poverty deeply because they live at home in the squatter house settlement, an environment where they are always directly confronted with poverty. Most women participants state that they have to deal with the needs of their children but are unable to fulfil them. This makes them feel unhealthy. In many cases, experiences related to poverty, such as children with unmet needs, responsibility for raising children or caring for a sick relative, confinement at home, capabilities not taken advantage of, and feeling helpless make them more susceptible to mental problems like depression.

Most women participants report suffering from fatigue in their villages because of the workload, whereas in the urban area they are comfortable physically but afflicted with depression due to poverty. They report that they had to work physically hard in rural areas, while tending livestock and working in the fields in addition to housework. For them, such work affected their physical health negatively, while being a housewife in an urban area affects their mental health negatively.

Women participants have many health complaints. Depression and low level of wellbeing are more prevalent among housewives, especially among those whose husbands are the main breadwinner or if there are no income earners. It is observed that they perceive the causes of their illnesses as being related to their general economic conditions. In addition, being a housewife in a squatter house means being vulnerable to many illnesses. The majority of housewife participants mention, having to do domestic duties such as washing clothes/dishes in the cold at home and raising children within inadequate living/sheltering conditions. One way of dealing with poverty among housewives is saving coal or wood by not heating the house when the husbands are at work and the children at school. They heat the home just before the children and husbands return.

\section{Perception of Health by Urban Poor}

The health conceptualization of the urban poor was explored through questions like, "what do you mean by health?", "How would you define a healthy person?", and "What are the prerequisites to being healthy?". The responses seem to point to different patterns in the health constructs. These vary according to poverty and working conditions, gender, age, as well as illness experience.

There appear to be four constructs peculiar to the urban poor: "health-illness" "health-tool", "health-product/consequences", and "health-peace of mind". It is difficult to draw clear lines between the participants' views on health, being a healthy person and the prerequisites of health, because the participants tended to blend these topics together during the conversations. Therefore, the health constructs were formed taking all into consideration.

A connection is evident between their personal experiences, views of their health/illnesses and their understanding of health. When asked what they mean by health, the respondents explain their illnesses after general definitions. When they believe their illnesses stem from malnutrition and inadequate shelter in the squatter house neighbourhood, they tend to focus the definition of health on living conditions such as adequate nutrition.

The urban poor perceive health in negative or positive ways. Despite usually defining health focusing on the negative, describing it as the "absence of illness", inability to move or do something, the participants gave positive definitions as well, mentioning health as function/tool/capital or as peace of mind and good wellbeing. 
In general, the urban poor experience ill health and poverty jointly. Variety in experiences diversifies their understanding of health. In addition, the difference among the urban poor in terms of gender, benefit dependency, age, employment position, role in the household, working conditions, and illness experiences make their understanding of health different.

\section{The health constructs of the urban poor}

\section{Health-illness construct}

The health-illness construct refers to seeing health as the absence of illness and the opposite of health. This is a "negative" understanding of health. The emphasis is on illness, whether physical or/and mental.

Many participants who see health as the "absence of illness" report a lack of contentment. Others think that being permanently sick has a detrimental effect on peace of mind and mental health. There are participants who see health as the "absence of illness" by focusing on physical and mental health jointly; only on mental health on which physical health is dependent; and only on physical health on which mental health is dependent. The majority of those who see health as the opposite of illness emphasize physical health. This construct is somewhat more common among the chronically ill and older participants or participants with chronically ill family members, especially if it is the breadwinner. Participants who define health as the "absence of illness" by focusing only on physical health explain the concept of health by relying on their own illness experiences, such as physical pain as the consequence of being permanently sick. Participants who see health as the opposite of illness typically define health by saying, "health is not having any diseases, complaints and/or pain" and a healthy individual is defined typically as, "If you have no illnesses, you are healthy".

M.D. (male, 39) is a gas station worker and among the regular income earning poor. The excerpt below is an example of the health-illness construct with a focus on the unity of mental health and wellbeing.

If you have no illness, you are healthy. Stress causes illnesses. Health means you have good mental health and feel good. A healthy person feels energetic and good.

Participants who see health as the opposite of illness are not concentrated in a specific social category. The life stories of participants display this pattern among men and women; benefit dependent poor and regular income earning poor; chronically ill participants or participants who have no chronic illness; and elderly or younger participants. More or less, they all express illness but they do not emphasize health and wellbeing. When they talk about a healthy person and the prerequisites of health, they do not talk about health but mostly illness. Frequently encountered illnesses and health complaints -chronic or temporary- of the participants themselves and/or other family member(s) seem to be influential in their emphasis on illness. Participants (or participants' family member(s)) who have an illness experience and/or are elderly tend to describe health (illness), especially physical health, in a negative way. On the one hand, participants from a regular income earning poor family also tend to define health as the absence of physical health. On the other, participants who are younger or of working age, benefit dependent poor, female, housewives and breadwinners working in the informal sector tend to focus on the importance of a working body (health as a tool), on a stable life, peace of mind and wellbeing, which fits other constructs. 


\section{Health-tool/capital construct}

The second construct is "health-tool", meaning the body and good health are seen as a tool or capital that enables movement, work, going to school, performing domestic tasks; in brief, "being capable of everything" according to the participants. Theoretically, it is actually a positive understanding of health, though the participants define health as being able to do something while still focusing on the negative. "An unhealthy person could not work, or easily move or perform daily tasks, could not take care of himself/herself" are typical negative statements made by participants.

The emphasis on being physically able to work is stressed by male participants working in the informal sector, especially as casual workers, unemployed male participants, female participants whose husbands (or other family members) are casual daily workers or unemployed, and the benefit dependent poor participants. The vicious cyclic nature of the relationship between health and work as mentioned in subjective illness accounts of urban poor are frequently expressed by the participants. H.T. (male, 39) is a casual/daily worker. He is unable to work every day and does not make a consistent living. He is a benefit dependent poor and he mentions that they have been getting worse off financially in the last 10 years. He says:

Health means being able to work. If you are healthy, you have a job. Having a job means money coming into the household. If you have no job, you are left out of the game.

In addition to work, participants' illness experiences influence their definition. Participants who have difficulty with physical movement due to illness tend to explain health in this way. The statements of the chronically ill and/or older participants, especially having difficulty moving and meeting personal needs, involve this type of explanation. Among the chronically ill participants, regular income earning poor participants tend to explain health, likening it to a tool by emphasizing physical health.

M.E. (female, 51) is a housewife whose husband has been bedridden for many years. Her son is the breadwinner and earns the minimum wage. However, she focuses on her husband's state, when she describes health. First, she defines health as the absence of mental illness. She has been experiencing depression for many years, which may be influencing the focus of her definition of health on mental illness. Then she mentions the importance of the capability of the body and working. She states:

You should be comfortable and have peace of mind. Stress and unhappiness makes you ill. You can't be comfortable without health. You can't work without health. It all starts with good health.

The sick, especially the chronically ill who have difficulty moving easily or (and) the elderly, define health using the tool construct or (and) health as the absence of illness in most cases as a consequence of their illness experiences. The below excerpt by M.F. (male, 74) expresses that:

Health is having good physical and mental health. It means having the energy to do all your work yourself, to be able to work. I feel healthy, when I can walk and move. I am ill now. I just had prostate surgery. I have also had atherosclerosis for 3 years. I haven't been able to get up for 2 months. I can't go about my affairs. My wife helps. I am also depressed but I am used to being ill by now.

M.F. defines health as being capable of work and being able to meet personal needs. A retiree, 
M.F. previously worked as a porter and furnaceman. His statements imply that he sees the body as a tool. The elderly and retired participants with chronic illness(es) also express their wellbeing by focusing on the lack of mobility necessary for daily activities, like M.F. They see feeling good as a privilege for those able to move and perform daily activities.

\section{Health-product/consequence construct}

This way of explaining health means viewing health as the consequence of something. This is the most complicated construct, because participants base their explanations on various factors resulting in health or illness. Poverty experiences are especially influential in the tendency to explain health/illness. In terms of health related beliefs about the causes of illness, the majority that defines health as a product/consequence focus on structural factors such as unemployment, irregular and/or low income, poverty experiences, inadequate nutrition and care, unhealthy living conditions, lack of adequate heating and lack of access to healthcare due to a lack of income. In addition to poverty experiences, behavioural factors such as harmful habits are mentioned by only a very few. No one placed initial focus on the influence of behavioural factors upon health; they are mentioned incidentally. Further, few participants, older and/or retired and/or those chronically ill tend to give fatalistic explanations like God or fate being responsible for health.

The responses to the question, "What are the prerequisites of being healthy?" are more homogenous than for the other two questions (about health and healthy individuals), and the fit health product or consequence construct includes three types of explanations: structural, behavioural and fatalistic. The typical structural factors mentioned are poverty, survival/financial difficulties, no money, low income, irregular income, unemployment, not meeting basic needs (food, shelter, clothing, heating, healthcare access) living in an inadequate physical environment, stress due to poverty/inconsistency, wealth, and so on. Although the question focuses on being healthy, the responses tend to explain the cause of being ill. For example, the participants who base their explanation on healthy behaviour such as taking care of themselves, balanced nutrition and exercising link their explanation to being wealthy. Fatalistic explanations about the causes of being ill are common for the chronically ill and used by older participants. Chronically ill younger participants tend not to give fatalistic explanations.

S.A. (male, 68) defines health, the healthy individual and the causes of illness as follows:

Your body can worsen in every way if your soul is in distress. You will be unhealthy if you don't have food, clothes, heating and shelter. All of these are important. If you don't have these, your brain gets tired. Poverty and illness are one and the same. Cleanliness happens with wealth. I would like to take a bath everyday. Health is taking care of yourself and living in a healthy way, so that you can be your own doctor. For that you need money. It is a human's basic need to be healthy. But is it possible under these conditions? That's why you can't be healthy. It's very important could you work or walk without it?

He starts with a focus on the negative influences of stress on the body due to poor financial circumstances, or poverty itself, and continues to define the healthy individual by focusing on mobility and the capability to work. Again, it is difficult to collect participants' views in one construct. S.A. sees health as illness, as a product, and as tool by emphasizing poor economic conditions.

In the other example, N.D. (female, 39) mentions poverty experiences, as many participants did. Lots of participants see illness as the same as poverty, like N.D.: 
Peace and having money means being healthy. Illness means being poor. If you have money you will have peace of mind and then health. Discontent comes from poverty.

Many participants who point out access to healthcare as a prerequisite of being healthy are all uninsured with no access to healthcare, benefit dependent poor, and participants who see their economic conditions having declined in the last 10 years. Also this explanation is common among participants (or a family member, especially children) with health complaints who cannot access healthcare freely. They point out that being able to access health care and undergoing regular check-ups are a determinant for being healthy. They typically state, "If you have access to healthcare and get regular check-ups, you are healthy."

E.A. (male, 26) explains health by focusing on healthcare access as a factor:

Being healthy is great. If you are well off, you will be healthy. Health depends on financial status. If you are ill you go to the hospital. We can't go, because we don't have money. If you go and you can't pay they detain you there. Then it's off to prison.

He is epileptic and permanently in contact with a hospital. He stated that he was nervous and suffered from arrhythmia when he is in the hospital. Also, something happened at the hospital that he did not mention until after the interview: he was held at the hospital against his will. When a traffic accident happened, 7 years before the interview date, he had no insurance, nor a Green Card for healthcare access. He was detained in the hospital until the hospital expenses were paid. His family had to use the money they had been saving to buy a squatter house. $\mathrm{He}$ was later released. Personal life experiences are obviously important.

\section{Health as peace of mind and wellbeing}

Among the participants, like the emphasis on illness, peace of mind is also frequently emphasized when talking about the meaning of health, being healthy and the prerequisites of being healthy. Although participants see health as a consequence of economic difficulties (health-product/consequence construct), or as tool (working, mobility), or even the absence of illness they frequently use the term "peace of mind" as a feeling. In this construct, participants refer to stability in life (regular income from a full time job with health care access) and wellbeing as the primary focus.

B.B. (male, 20) explains the meaning of health, being a healthy person and the prerequisites of being healthy as:

It means to feel physically and mentally well. It is getting up happy in the morning. A healthy person says I will do this and that today. He makes plans and likes to live. Regular exercise, a good diet, sleeping well. These will happen if there are no work problems and having a regular income. A healthy person is energetic and has peace of mind. If you feel bad mentally, your body will worsen. If you have harsh working conditions and an irregular job you get ill, like my mother. An unhealthy person can't get out of bed in the morning. He can't go to work or school, can not study.

The first statement by B.B. reflects this construct in a way that unifies physical and mental health. It can be said that he defines health in a positive way. Among the participants who see health as peace and wellbeing, the tension between physical health and wellbeing is felt. Some only focus on physical health, some base their explanation on mental health, and some emphasize 
the relationship between the two. He also sees good health as the result of economic factors. Lastly, he sees being healthy as having the capability to continue everyday life.

The excerpt from N.B.'s (female, 26) response is typical for this construct. She is a housewife and her husband is in the single breadwinner position. He works as a seasonal garden cleaner and is otherwise a casual worker. His income is irregular. N.B. says, "you are healthy if you have peace of mind". In this case, the emphasis is on wellbeing.

It is striking that very few participants with long-term illness(es) see health in a positive way, although they frequently mention their illness experiences during the interview. İ.Ö. (Male, 40) focuses on physical health. He has suffered from diabetes mellitus for 20 years and has been living dependent on dialysis three times a week due to kidney failure for 5 years. He is a benefit dependent poor and does not earn money. His family survives with formal and informal social assistance. Although he has been chronically ill for a long time and he accepts the role of being sick, he discusses his wellbeing in a positive way. He also gives a general explanation of health emphasizing physical health rather than illness.

\section{If the body is healthy you will be healthy. Your mood and peace of mind depend on it. Someone whose body works peacefully is healthy.}

The typical positive answers for this construct are like having a stable life, being comfortable, being contented, having peace of mind, happiness, good wellbeing and mood, physical and mental wellbeing. Participants who see health as peace of mind usually define health positively, but negative explanations are also given like instability, the absence of contentment or peace of mind, or lack of wellbeing. Although many participants frequently state "peace of mind", it is observed that women tend to see health like this. Many women respondents state the prerequisite of being healthy by emphasizing not peace of mind but bad moods, the absence of peace of mind, absence of stability, being stressful and feeling dejected, and typically they tend to emphasize dejection stemming from irregular income. As mentioned before, women experience poverty differently from men. They feel helpless against poverty. Therefore, they frequently base their explanation of health on stability and peace of mind. They mention the close relationship between poverty experiences and wellbeing. In addition to women participants, unemployed young participants, and breadwinner participants who earn irregular money and do not have a full-time job with social security benefits tend to focus on peace of mind and wellbeing. Also a few younger male participants with chronic illness emphasize peace of mind. It is common among those who are unemployed because of the sick role.

Asked about their view about the prerequisites for being healthy, some (especially women) participants attribute being healthy to good wellbeing/absence of dispiritedness. A few also provide positive explanations, saying health is happiness and cheerfulness.

\section{Conclusion and Discussion}

The analysis of the participants' subjective self-reports of their health and wellbeing, the causes they perceive as resulting in their wellbeing and illness, how they define/explain health, being healthy, the prerequisites and the causes underlying health, being healthy and being ill have been of primary concern in this study. Findings show that there are many similarities but also significant differences among the urban poor in the ways that they perceive health. The differences are determined based on age, gender, and whether or not they have a chronic illness. Other criteria determining their health perceptions have been related to their experiences of poverty, including unemployment, healthcare access, type of employment, and benefit dependency status. In consequence, the urban poor cannot be lumped together into a homogenous 
mass. There appears to be a close relationship between health perception and poverty and illness experiences. Also, social status in the family, in the labour market and in society results in a different experience of poverty, and thus perception of health. Ultimately, four health constructs come to the fore: health as a product or consequence, health as the absence of illness, health as a tool, and health as peace of mind and wellbeing.

We can conclude that the urban poor, in general, define health with more than one focus; for the most part, the participants' statements fit two or three constructs. Doing this, the constructs do not essentially conflict with each other; rather the participants relate them to each other. At the same time, they try to integrate mental and physical health and wellbeing and tend to see them as interlinked. Unlike the medical view, they do not make a mind versus body distinction.

In general, when asked directly, "what is health?" the urban poor tend to focus their explanation on illness. In fact, they tend to explain illness, more precisely bad mood/wellbeing within the context of their everyday hardship. For them, illness is inherent in poverty; health is associated with being wealthy. Similarly, for Pierret (1995), health is a primary focus for middle class people, while manual workers and small-farmers see health as illness and a tool. In our study, similar to Pierret, d'Houtaud and Field's $(1984,30)$ findings, the lower manual labouring classes describe health "more in negative, socialized and instrumental terms".

In terms of the perceived causation of illness, the urban poor tend to give more structural explanations by focusing on their living conditions. In many studies like those of Herzlich (1973), Helman (1981), Blaxter, (1983; 1990), illness is external to the individual. Among them, Herzlich's (1973) finding that respondents distinguished clearly between illness -the negative concept- which was produced by ways of life, which was also recorded in our study. The structural orientation of the explanations provided by the urban poor match the healthproduct/consequences construct. However, it is striking that in our study, unlike many studies' findings on diverse participants (e.g. Pill and Stott 1982; Blaxter 1983; 1990, Tekin 2007; GelgeçBakacak 2008; Adak 2002; etc.), germs or infection was not found as being the main perceived cause of diseases. While both Blaxter (1983; 1990), Helman (1981) and Pill and Stott (1982) state that the medical model of disease has permeated the lay perspective, in our study this finding was not observed. It seems that neither the medical terminology nor the medical perspective has penetrated the participants' lay perspective, although they, especially women and children, use health services for various illnesses, at least those who have access to it.

The most common explanation given, fits the health-product/consequence construct, in which participants explain by focusing on social factors, especially meeting basic needs, economic difficulties, working conditions, low and irregular income and healthcare access. This construct is different from Pierret's in terms of content. According to her findings, similar to d'Houtaud and Field's (1984), the interviewees explanation fits the health-product "took health to be an objective to be reached, but they thought that reaching it depended on several factors" (Pierret 1995, 15). This construct is prevalent among middle class people, imply "outcomes of set of factors", and it was found to be associated with a view of health as an end and not a tool (Pierret 1995, 18). In contrast, our participants see a healthy body as a tool and not as an objective. Instead, on the one hand they see health as tool; on the other hand, they draw a close association specifically between poverty and health (actually illness). Unlike in other constructs, a considerable number of participants who define health as a product explain only by focusing on health as a consequence of such factors, especially the structural one. Here the experiences of poverty are central. Among the benefit dependent poor respondents, the explanation based on health as the result of economic factors is more common. For those who are uninsured, access to 
healthcare is important in their definition of themselves as healthy.

Shilling (1993), Pierret (1995), d'Houtaud and Field (1984), Pierret (1995) have similar findings that manual, poor or working class people's orientation towards health, illness and the body is as towards a tool, capital or a means for job, not as an end or objective to be reached. The findings seem to correspond, to a large extent, with previous studies' findings such as Shilling's similar distinction of "means to an end" and "an end in itself" for different classes, the study of d'Houtaud and Field (1984), and Pierret's (1995) health construct. In particular, the health of male and working members in families is a strong priority because they are the ones considered the main breadwinners. Their body must remain strong and healthy to ensure that the family is provided for because they hold manual jobs. This priority on the healthy male breadwinner is supported by the family members in general, and most specifically by the women respondents. This kind of perception puts women at the bottom of the list, ranking them after husbands, sons and daughters. In addition to breadwinners, this construct is mentioned by elderly and/or chronically ill participants, saying that health is a tool ensuring mobility, the ability to do daily tasks and meet their needs on their own.

Blaxter's study (1990) found that the elderly who feel of decreasing value, unlike the younger people, give a negative explanation of health. Older participants in our sample do not fit into the category of health as reserve, but mostly, the health-illness and health-tool constructs. The sick, in particular the chronically ill and/or the elderly, tend to explain health in accord with the health-as-a-tool construct by saying, "health is having the strength and the ability to do everything; working and performing daily activities" and/or with the construct, health as the absence of illness. Other constructs such as health as fitness, vitality, energy, an end in itself and behaviour were not found among our participants.

The health-as-peace-of-mind-and-wellbeing construct emerged in this study and is peculiar to the urban poor. Especially women whose husbands or themselves have the breadwinner role in the family tend to define health as peace/wellbeing, in addition to health as product/consequence. Women assign importance to the position of breadwinner, and tend to focus on mood by mentioning peace of mind, which in fact connotes stability (e.g. regular wage, thus stable life). This is most commonly stated by benefit dependent poor family members. In fact, they do not define health in positive terms. Their definition involves more negativity and their unstable life, unpredictable income, often no income at all, unemployment and so on. They report feeling helpless, thus lacking peace of mind within their context of poverty. Our findings bear similarities with Cornell's (1984) findings in that the gendered division of labour, daily hardships and therefore the social context, are all crucial for women's definition of health, illness and responses to illness. In this construct, the other participants that focus on peace and wellbeing but in a positive way are either older and/or chronic patients. They define health by focusing on social support, state benefits and having a good relationship with family members despite their many diseases. It should be noted that very few participants reported this type of outlook. In this study, this pattern is found in this construct; however, Herzlich (1973) defines it as a distinct construct in her study (health despite illness).

\section{Funding}

The data presented in this article is a part of Özen's PhD thesis (supervised by RittersbergerT11ıç) entitled "Health and Illness Experiences among the Urban Poor: The Case of Altındağ" of the sociology department at the Middle East Technical University in 2008. The thesis was supported financially by the Middle East Technical University Scientific Research Project. 


\section{REFERENCES}

Adak N. (ed.) (2016). Sağllk Sosyolojisinde Güncel Tartışmalar. Ankara 2016.

Adak N. (2002). Sağlık Sosyolojisi: Kadın ve Kentleşme. İstanbul 2002.

Akşit B. \& Akşit B. (1997). "Mother's Education, Differential Child Valuation and Infant/Child Mortality”. Eds. L. Visaria, J. Simons, P. Berman. Mother's Education and Child Survival: Pathways and Evidence (2009) 128-135. New Delhi.

Akşit B. \& Akşit B. (1989). "Socio-Cultural Determinants of Infant and Child Mortality". Social Sciences and Medicine 28/6 (1989) 571-579.

Akşit B. T. (1993). "Rural Health Seeking: Under Fives in Sivas, Van and Ankara". Ed. P. Stirling. Culture and the Economy: Changes in Turkish Villages (1993) 156-170. Cambridgeshire.

Alptekin D. (ed.) (2015). Hasta Toplum. Ankara 2015.

Ayata A. \& Ayata S. (2003). "The Benefit Dependent and the Regular Income Earning Poor: The Analysis of the Interview Data". Turkey: Poverty and Coping After Crisis Vol: II, Background Papers. World Bank, Human Development Unit Europe and Central Asia Region. Report no: 24185-TR.

Benzeval M., Judge K. \& Whitehead M. (1995). Tackling Inequalities in Health: An Agenda for Action. London 1995.

Blaxter M. (1990). Health and Lifestyle. London 1990.

Blaxter M. (1983). “The Causes of Disease: Women Talking”. Social Science and Medicine 17 (1990) 5969.

Blaxter M. \& Paterson E. (1982). Mothers and Daughters. A Three-Generational Study of Health Attitudes and Behaviour. London 1982.

Boratav K. (1995). İstanbul ve Anadolu'dan Sinuf Profilleri. İstanbul 1995.

Bury M. (1982). "Chronic Illness as Biographical Disruption”. Sociology of Health and Illness 4 (1982) 167-182.

Bury M. (1991). "The Sociology of Chronic Illness". Sociology of Health and Illness 13/4 (1991)451-468.

Bury M. (2001). "Illness Narratives. Fact or Fiction?” Sociology of Health and Illness 23/3(2001) 263-285.

Bury M. (2005). Health and Illness. Cambridge 2005.

Cirhinlioğlu Z. (2000). Sağllk Sosyolojisi. Ankara 2000.

Cornwell J. (1984). Hard-Earned Lives. Accounts of Health and Illness from East London. London 1984. d'Houtaud A. \& Field M. G. (1984). "The Image of Health”. Sociology of Health and Illness 6 (1984) 30-60.

Dodd R., Hinshelwood E. \& Harvey C. (2004). PRSPs: Their Significance for Health: Second Synthesis Report. Geneva 2004.

Gelgeç-Bakacak A. (2008). Normal/Patolojik Ayrımı Çerçevesinde Akıl Hastalığına Bakışa iliş̧kin Niteliksel Bir Araştırma. Unpublished PhD Thesis. Hacettepe Üniversitesi, Ankara 2008.

Gönç Şavran T. (2010). Toplumsal Eşitsizlikler ve Sağllk: Eskişsehir'de Sosyolojik Bir Araştırma. Unpublished PhD Thesis. Anadolu Üniversitesi, Eskişehir 2010.

Gürsoy A. (1992). “Infant Mortality: A Turkish Puzzle?” Health Transition Review 2/2 (1992) 131-49.

Gürsoy A. (1995). "Child Mortality and the Changing Discourse on Childhood in Turkey". Ed. E. W. Fernea. Children in the Muslim Middle East (1995). Austin.

Gürsoy A. (1996). "Beyond the Orthodox: Heresy in Medicine and the Social Sciences from a CrossCultural Perspective". Social Science and Medicine 43/5 (1996) 577-99.

Health Poverty Action (2017). Annual Report \& Accounts 2016-2017.

(https://www.healthpovertyaction.org/wp/wp-content/uploads/2012/06/HPA-Annual-Report-20171.pdf. Accessed 23 April, 2017).

Helman C. (1981). "Disease versus Illness in General Practice". Journal of the Royal College of General Practitioners 31 (1981) 548-552.

Herzlich C. (1973). Health and Illness. London 1973. 
Kardam F. \& Yüksel Alyanak İ. (2002). "Kadınların Yoksullukla Başetme Yolları”. Ed. G. Erdost. Türkiye Insan Haklart Hareketi Konferansı 2002 Bildirileri (2002) 209-224. Ankara.

Kasapoğlu A. (2008) (ed.). Madalyonun İki Yüzü: Sağllk ve Hastalı. Ankara 2008.

Kasapoğlu A. (1999). Sağglı Sosyolojisi: Türkiye'den Araştırmalar. Ankara 1999.

Lawton J. (2003). "Lay Experiences of Health and Illness: Past Researches and Future Agenda". Sociology of Health and Illness 25 (2003) 23-40.

Lordoğlu K. \& Özar Ş. (1998). Enformal Sektör ve Sosyal Güvenlik: Sorunlar ve Perspektifler. İstanbul 1998.

Nettleton S. (1995). The Sociology of Health and Illness. Cambridge 1995.

OECD \& WHO (2003). Poverty and Health. Paris 2003.

Öngören B. (2011). Fizyolojik, Sosyal ve Kültürel Açılardan Sağlıklı Beden İmgesi. Unpublished PhD Thesis, Ege Üniversitesi, İzmir 2011.

Özbay F., Terzioğlu A. \& Yasin Y. (eds.) (2011). Neoliberalizm ve Mahremiyet: Türkiye'de Beden, Sağllk ve Cinsellik. İstanbul 2011.

Özen, Y. (2008). Health and Illness Experiences among the Urban Poor: The Case of Alttnda $\breve{g}$. Unpublished PhD Thesis, Middle East Technical University, Ankara, 2008.

Pierret J. (2003). "The Illness Experience: State of Knowledge and Perspectives for Research". Sociology of Health and Illness 25 (2003) 4-22.

Pierret J. (1995). "Constructing Discourses about Health and Their Social Determinants". Ed. A. Radley. Worlds of Ilness: Biographical and Cultural Perspectives on Health and Illness (1995) 9-26. London.

Pill R. \& Stott N. C. H. (1982). "Concept of Illness Causation and Responsibility: Some Preliminary Data from A Sample of Working Class Mothers". Social Science and Medicine 16 (1982) 43-52.

Shilling C. (1993). The Body and Social Theory. London 1993.

Tekin A. (2007). Sağllk-Hastalık Olgusu ve Toplumsal Kökenleri. Unpublished Master Thesis. Süleyman Demirel Üniversitesi, Isparta 2007.

Türkdoğan O. (1991). Kültür ve Sağllk-Hastallk Sistemi: Doğu'da Bir Kasabanın Tıbbi Sosyoloji Açısından İncelenmesi. İstanbul 1991.

Williams G. (1984). "The Genesis of Chronic Illness. Narrative Reconstruction". Sociology of Health and Illness 6 (1984) 175-200.

Williams R. (1983). "Concepts of Health: An Analysis of Lay Logic". Sociology 17/2 (1983) 185-205.

Williams S. J. (1995). “Theorising Class, Health, Lifestyle: Can Bourdieu Help Us?”. Sociology of Health and Illness 17/5 (1995) 577-604. 
